\title{
The role of citizenship education in development of urban branding
}

\author{
Farangis Heshmati ${ }^{a^{*}}$, Tarkan Hosseini ${ }^{b}$ and Yasmin Keyvan
}

${ }^{a}$ Masters Student, Department of Social Sciences, Shahid Bahonar University, Kerman, Iran

${ }^{b}$ Masters Student, Department of Business Administration and Export Affairs, Payam Noor University of Tehran West, Tehran, Iran

${ }^{c}$ Masters Student, Department of Business Administration, Science and Research Branch, Islamic Azad University, Tehran, Iran

\section{H R O N I C L E}

Article history:

Received January 5, 2016

Received in revised format April

15,2016

Accepted April 20, 2016

Available online

April 21, 2016

Keywords:

Urban branding

Perceived control

Subjective norm

Intend

\section{A B S T R A C T}

\begin{abstract}
This paper presents a survey on the role of citizenship education in development of urban branding in city of Tehran, Iran. The study considers the effects of attitude, subjective norms, perceived control and intend adopted by the local community on development of urban branding. We design a questionnaire in Likert scale and distributes it among 400 randomly chosen people in city of Tehran, Iran. Cronbach alphas for all components of the survey are well above the desirable level. Using Pearson correlation test as well as stepwise regression techniques, the study has determined a positive and meaningful effects of perceived control and intend adopted by the local community on urban branding.
\end{abstract}

(C) 2016 Growing Science Ltd. All rights reserved.

\section{Introduction}

Cities throughout the world are increasingly adapting the concept and methods of product branding for place marketing, in pursuit of wider urban management objectives, especially within the new circumstances (Ashworth \& Kavaratzis, 2009). However, there is a little consensus about the nature of city branding, let alone its role in public sector urban planning and management (Kavaratzis \& Ashworth, 2006). Regional marketing is a method for shaping the internal advantages of the region, investment and economic development factors, increasing attractiveness of the area as a whole (Bagautdinova et al., 2012). Kavaratzis and Ashworth (2005) applied contemporary developments in marketing theory and practice to determine how product branding could be transformed into city branding as a powerful image-building strategy, with substantial relevance to the contemporary city. It also defined city branding, as it is being currently understood by city administrators and critically investigated its contemporary implementation so that a framework for an effective place branding strategy could be built.

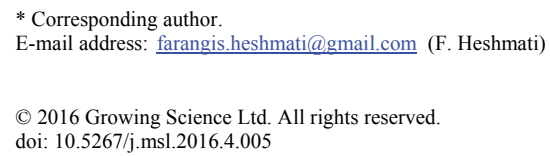


Zhang and Zhao (2009) investigated the impacts of efforts to brand Beijing, the capital city of China. They tried to find out to what extent the current campaign could catch the city's good attributes. They determined a mismatch between the identity and core values as branded by the city government, and the realities as experienced by visitors and residents. Grodach and Loukaitou-Sideris (2007) explained the development of municipal cultural strategies in the United States, and draws the characteristics of three various models of such strategies. The study has indicated that although most agencies were guided by different objectives, entrepreneurial objectives continue to learn the development and support of cultural activities in most cities.

Gold and Gold (2008) explored the significance of being an Olympic city. They reported that the changing agendas that host cities had brought to bear on staging the Games. Knowledge-based development strategies play an essential role in helping local economic development of cities in the knowledge era. Yigitcanlar and Velibeyoglu (2008) studied local knowledge-based urban development policies of Brisbane, Australia in its long journey to become a competitive knowledge city. They studied Brisbane's recent progress towards building knowledge community precincts which were important creative urban environments to absorb and keep global investment and talent. Kong (2007) investigated the efforts by Shanghai's, Singapore's and Hong Kong's governments to develop cultural icons as part of the strategy to improve their cities obtain global city status, and in the process, building shared national and city identities. Zhao (2015) tried to determine how people between the public and private sectors in heritage management were functioned as a method for city branding, and how local people were influenced by these partnerships. They also considered opinions from the local general public about these partnerships, and investigated the complex relationships among local government, elite entrepreneurs, and the public.

\section{The proposed study}

This paper presents a survey on the role of citizenship education in development of urban branding in city of Tehran, Iran. The study considers the effects of attitude, subjective norms, perceived control and intend adopted by the local community on development of urban branding. The sample size of the population is calculated as follows,

$$
N=Z_{\alpha / 2}^{2} \frac{p \times q}{e^{2}},
$$

where $N$ is the sample size, $p=1-q$ represents the probability, $z_{\alpha / 2}$ is CDF of normal distribution and finally $\varepsilon$ is the error term. For our study we assume $p=0.5, z_{\alpha / 2}=1.96$ and $e=0.05$, the number of sample size is calculated as $N=384$. We have decided to distribute 400 questionnaires among the selected participants in our survey. Fig. 1 demonstrates personal characteristics of the participants.

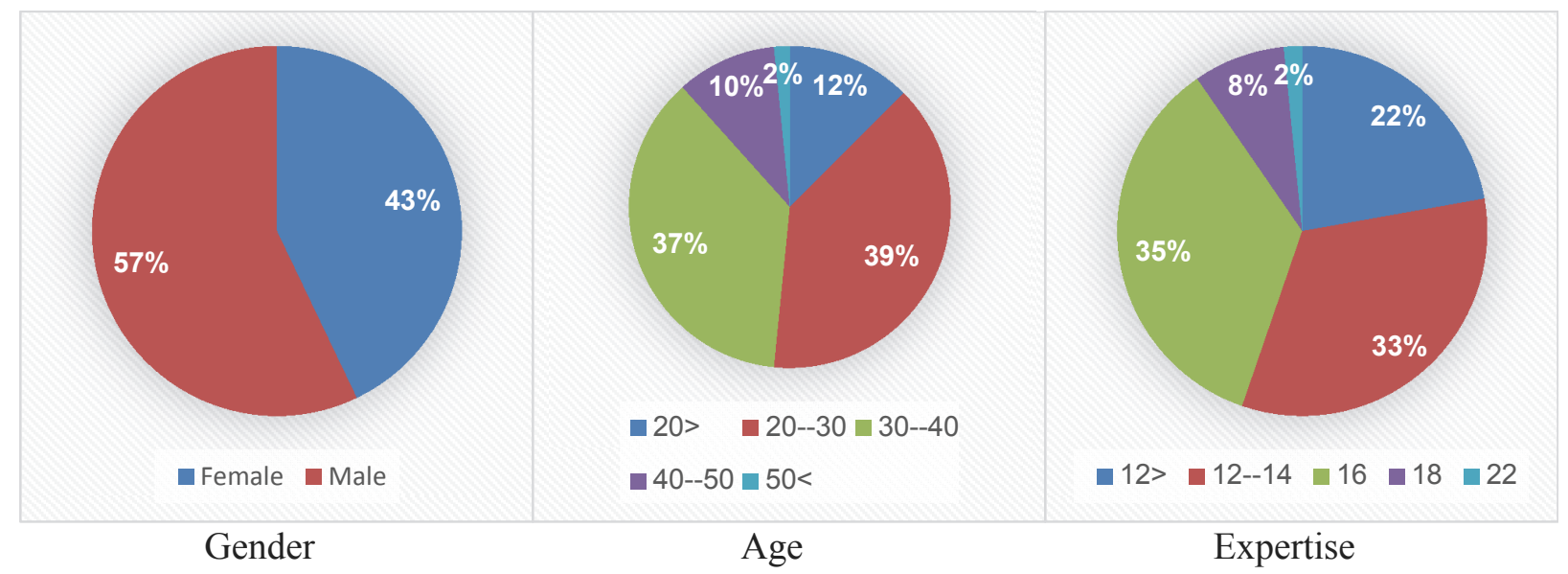

Fig. 1. Personal characteristics of the participants 
As we can observe from the results of Fig. 1, more than half of the participants were middle aged people with good university educations. The proposed study considers the following four hypotheses (See Fig.2),

Hypothesis 1: Citizens' attitudes to learning and citizenship education are associated with the development of urban branding.

Hypothesis 2: Citizens' subjective norms to acquire citizenship education are associated with the development of urban branding.

Hypothesis 3: Citizens' perceived controls to acquire citizenship education are associated with the development of urban branding.

Hypothesis 4: Intention and willingness to learn citizenship education are associated with the development of urban branding.

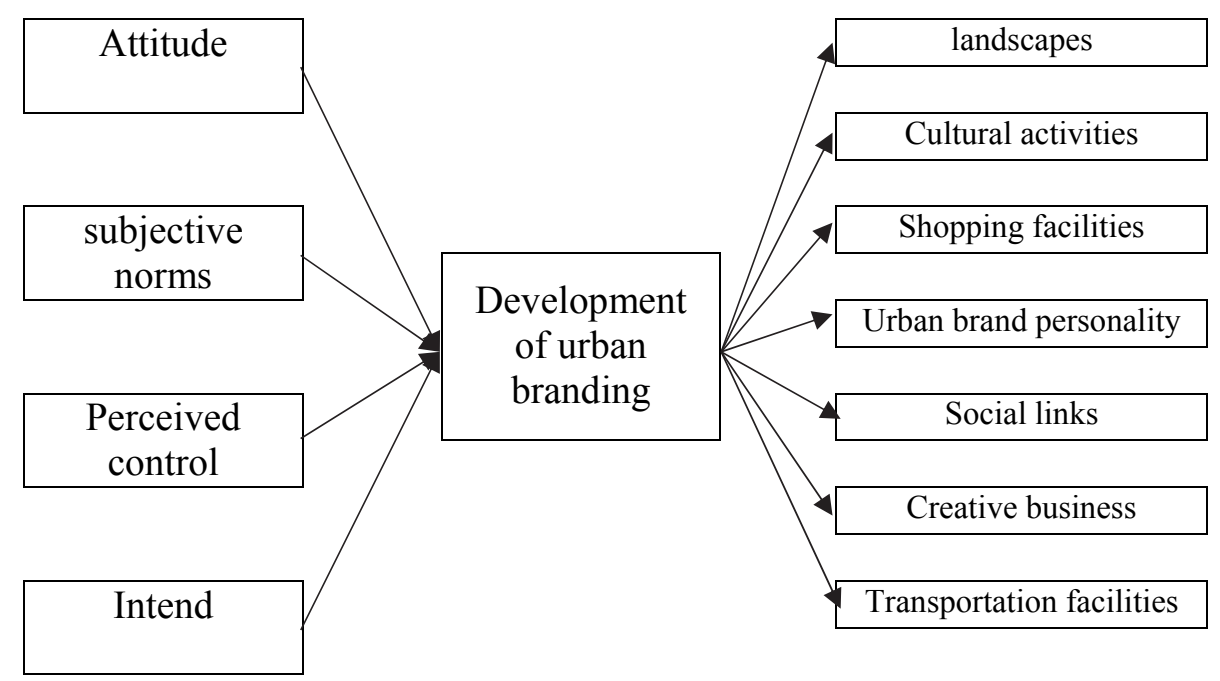

Fig. 2. Structure of the proposed study

\section{The results}

In this section, we present details of the findings of the proposed study. Cronbach alphas for all components of the survey have been well above desirable level. The implementation of KolmogorovSmirnov has indicated that the data were normally distributed. Table 1 shows the results of Pearson correlation for hypotheses of the survey.

Table 1

The results of Pearson correlation test

\begin{tabular}{ccccc}
\hline Hypothesis & Pearson correlation & Sig. & Test level & Result \\
\hline 1 & .375 & .003 & .05 & Confirmed \\
2 & .281 & .000 & .05 & Confirmed \\
3 & .495 & .0007 & .05 & Confirmed \\
4 & .483 & .000 & .05 & Confirmed \\
\hline
\end{tabular}

According to the results of Table 1, Citizens' perceived control maintains the highest positive impact on development of urban branding followed by intention to learn, attitude and subjective norm. Next, Table 2 presents details of our findings on the implementation of stepwise regression method. 


\section{Table 2}

The summary of stepwise regression

\begin{tabular}{lccccc}
\hline Variable & coefficient & Standard error & Standard coefficient & t-value & Sig. \\
\hline Intercept & 56.219 & 5.041 & & 18.816 & .000 \\
Perceived control & .599 & .293 & .382 & 3.419 & .0006 \\
Intention & .491 & .166 & .261 & 3.383 & .0013 \\
\hline Adjusted R-Square $=0.198$ & & & &
\end{tabular}

According to the results of Table 3, two independent variables of the survey, perceived control and intention, have matained the highest positive impacts on development of urban branding. Adjusted RSquare is equal to 0.198 , which means the independent variables, perceived control and intention, describe nearly $20 \%$ of the changes on dependent variable, development of urban branding.

\section{Conclusion}

In this paper, we have presented an empirical investigation to study the effects of attitude, subjective norms, perceived control and intend adopted by the local community on development of urban branding in city of Tehran, Iran. The results of our survey have indicated that perceived control and intention, have maintained the highest positive impacts on development of urban branding. Based on the results, by increasing citizens' awareness on their rights and duties, we may expect an increase on urban branding. In addition, development of effective incentive systems to encourage citizens to learn citizenship education is also another method to develop city branding.

\section{Acknowledgement}

The authors would like to thank the annonymous referees for constructive comments on earlier version of this paper.

\section{References}

Ashworth, G., \& Kavaratzis, M. (2009). Beyond the logo: Brand management for cities. Journal of Brand Management, 16(8), 520-531.

Bagautdinova, N., Gafurov, I., Kalenskaya, N., \& Novenkova, A. (2012). The regional development strategy based on territorial marketing (the case of Russia). World Applied Sciences Journal, 18(18), 179-184.

Gold, J. R., \& Gold, M. M. (2008). Olympic cities: regeneration, city rebranding and changing urban agendas. Geography compass, 2(1), 300-318.

Grodach, C., \& Loukaitou-Sideris, A. (2007). Cultural development strategies and urban revitalization: A survey of US cities. International Journal of Cultural Policy, 13(4), 349-370.

Kavaratzis, M., \& Ashworth, G. J. (2005). City branding: an effective assertion of identity or a transitory marketing trick?. Tijdschrift voor economische en sociale geografie, 96(5), 506-514.

Kavaratzis, M., \& Ashworth, G. J. (2006). City branding: An effective assertion of identity or a transitory marketing trick?. Place Branding, 2(3), 183-194.

Kong, L. (2007). Cultural icons and urban development in Asia: Economic imperative, national identity, and global city status. Political Geography,26(4), 383-404.

Yigitcanlar, T., \& Velibeyoglu, K. (2008). Knowledge-based urban development: The local economic development path of Brisbane, Australia.Local Economy, 23(3), 195-207.

Zhao, Y. (2015). 'China's leading historical and cultural city': Branding Dali City through public-private partnerships in Bai architecture revitalization.Cities, 49, 106-112.

Zhang, L., \& Zhao, S. X. (2009). City branding and the Olympic effect: A case study of Beijing. Cities, 26(5), $245-254$.

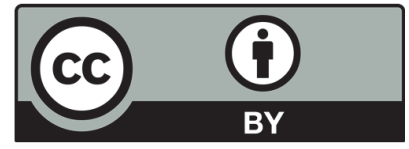

(C) 2016 by the authors; licensee Growing Science, Canada. This is an open access article distributed under the terms and conditions of the Creative Commons Attribution (CC-BY) license (http://creativecommons.org/licenses/by/4.0/). 